\title{
Studies on inhibition of $\mathrm{H}_{2} \mathrm{O}_{2}$ induced TGF- $\beta$ I expression in peripheral blood mononuclear cells by novel pyridine appended lutein derivative
}

\begin{abstract}
Lutein a hydroxy carotenoid belonging to xanthophyll group having a hydroxyl group attached to either end of the molecule, making it react more strongly with singlet oxygen than other carotenoids. In the present study, Lutein was modified by appending pyridine moiety for increased antioxidant activity and its ability to inhibit $\mathrm{H}_{2} \mathrm{O}_{2}$ induced TGF- $\beta 1$ expression in peripheral blood mononuclear cells was investigated. Lutein was treated with Isonicotinic acid (Pyridine-4-carboxylic acid) in the presence of DCC and DMF as solvent medium to obtain pyridine appended Lutein $(2.28 \mathrm{mg} / \mathrm{ml})$. The pyridine appended Lutein was purified using silica gel-G (60-120mesh) column, further by HPLC and fractions were eluted at the rate of $1 \mathrm{ml} / \mathrm{min}$ using water, acetonitrile, methanol and dichloromethane as mobile phase in the ratio $0.5: 9.5: 67.5: 22.5$. A major peak was obtained at $454 \mathrm{~nm}$ with retention time of $1.60 \mathrm{~min}$. In dose dependent study, Pyridine appended Lutein at $0.42 \mu$ moles showed a maximum of $91.6 \%$ of DPPH radical scavenging activity in comparison to unmodified Lutein $(80.76 \%)$. Unmodified Lutein showed maximum activity $(86.18 \%$ at $1.25 \mu$ moles) with 2.97 folds higher than Pyridine appended Lutein. TGF- $\beta 1$ expression in $\mathrm{H}_{2} \mathrm{O}_{2}(3 \mathrm{mM})$ treated peripheral blood mononuclear cells was inhibited by $83.14 \%(152.1 \mathrm{pg} /$ $\mathrm{ml})$ and $76.21 \%(214.62 \mathrm{pg} / \mathrm{ml})$ at $0.92 \mu$ moles of Pyridine appended Lutein and unmodified Lutein respectively compared to $\mathrm{H}_{2} \mathrm{O}_{2}$ treated cells $(902.15 \mathrm{pg} / \mathrm{ml})$ without test samples. In conclusion, Pyridine appended Lutein showed higher DPPH radical scavenging activity and inhibited $\mathrm{H}_{2} \mathrm{O}_{2}$ induced TGF- $\beta 1$ expression in peripheral blood mononuclear cells at low concentrations than unmodified Lutein.
\end{abstract}

Keywords: DPPH radical, isonicotinic acid, n,n'-dicyclohexylcarbodiimide, n,ndimethyl formamide, lutein, TGF- $\beta 1$
Volume 3 Issue 4 - 2016

\author{
Mukunda Chethankumar,' Syeda Hajira \\ Banu,' Latha BV,' Sathish Kumar BY,' \\ Mallesha $\mathrm{L}^{3}$ \\ 'Department of Biochemistry, JSS CACS (autonomous of \\ University of Mysore), India \\ ${ }^{2}$ Department of Biotechnology, JSS CACS, (autonomous of \\ University of Mysore), India \\ ${ }^{3}$ Department of Chemistry, JSS CACS, (autonomous of \\ University of Mysore), India
}

Correspondence: Mukunda Chethankumar, Department of Biochemistry, JSS CACS (autonomous of University of Mysore), Mysuru City, Karnataka State, India, Tel +918884345956, +91082 I25482 I6, Fax +91082I2548238,

Email chethankumar.m@gmail.com

Received: April 06, 2016 | Published: May 20, 2016

\section{Introduction}

Carotenoids are fat soluble naturally occurring pigments that are synthesized by plants and microorganisms, serving a variety of roles in cell biology. ${ }^{1}$ Carotenoids are the pigments that involve in light harvesting to participate in energy transfer process in photosynthesis. They absorb light in the 400-500nm region of the visible spectrum and impart coloration of yellow, orange, red, and purple. ${ }^{2}$ They are widely distributed in nature including vegetables, fruits, insects, fishes, and birds. Animals are incapable of synthesizing carotenoids, hence should be obtained through diet. ${ }^{3}$ Among 700 carotenoids, 40 of them are present in the human dietary source and 20 carotenoids are present in the human blood and tissues. ${ }^{4,5}$ Lutein and Zeaxanthin belong to the xanthophyll family of carotenoids and are the two major components of the macular pigment of the retina. ${ }^{6}$ Lutein and Zeaxanthin differ from other carotenoids in that they each have two hydroxyl groups. The hydroxyl groups appear to control biological function of Lutein and Zeaxanthin. ${ }^{7}$ Lutein ( $\beta$, $\varepsilon$-carotene-3, $3^{\prime}$-diol, $\mathrm{C}_{40} \mathrm{H}_{56} \mathrm{O}_{2}$ ) has no provitamin A activity and has two rings: one $\beta$-ring and another $\varepsilon$-ring hydroxylated at the 3 and $3^{\prime}$ position. It consists of eight isoprenoid units which appear as a conjugated double bond. The isoprenoid arrangement is reversed at the center of the molecule, so that the two central methyl groups are in $\alpha 1,6$-position and the remaining non-terminal methyl groups are in $\alpha 1,5$-position. ${ }^{8}$

The naturally occurring carotenoids are efficient antioxidants. ${ }^{9,10}$
Lutein is shown to possess pronounced free radical scavenging ability due to its polarity and number of conjugated double bonds, ${ }^{11}$ however chemical synthesis of their derivatives has proven to be better in their biological activity. ${ }^{12}$ Lutein-6H-1,2-oxazine along with 14-s-cis-5-nitrolutein is reported to exhibit better scavenging activity of peroxynitrite and nitrogen radicals. ${ }^{13}$ 15-nitroastaxanthin, derivative of astaxanthin is reported to inhibit in vitro Epstein-Barr virus early antigen activation and two-stage carcinogenesis in mouse skin papillomas. Similar results are reported for the 15-nitrolutein, a major reaction product of lutein with peroxynitrite. ${ }^{14}$ Partial synthesis of (3R, 6'R)-alpha-cryptoxanthin and (3R)-beta-cryptoxanthin from $\left(3 \mathrm{R}, 3^{\prime} \mathrm{R}, 6^{\prime} \mathrm{R}\right)$-lutein is reported with significant biological activity. ${ }^{15}$ ROS such as superoxide anion $\left(\mathrm{O}_{2} \bullet-\right)$, hydrogen peroxide $\left(\mathrm{H}_{2} \mathrm{O}_{2}\right)$, and hydroxyl radical $(\mathrm{OH} \bullet)$, participate in cell signaling and/or injury.16 $\mathrm{H}_{2} \mathrm{O}_{2}$, in most biological contexts, is generally less reactive and long-lived than either superoxide anion or hydroxyl radical. $\mathrm{H}_{2} \mathrm{O}_{2}$ is shown to mediate intracellular signal transduction by its ability to oxidize cysteine residues in the catalytic domains of protein tyrosine phosphatises. ${ }^{17}$ ROS have been shown to mediate TGF- $\beta$ induced cellular responses in various cells. ${ }^{18,19}$ TGF- $\beta$ is a multifunctional cytokine that regulates variety of physiological process, including cell growth, differentiation, profibrotic gene expression, fibroblast proliferation and is a key regulator of fibrosis. ${ }^{20}$

The pyridine nucleus is an important hetero aromatic class of compounds with a wide range of activities. Nicotinic acid 
derivatives and its isomers have also been investigated as an agent for the prevention or delay of the onset of type 1 diabetes mellitus. They also have anti-bacterial, anti-oxidant, anti-inflammatory and anti-carcinogenic activities, and have putative activity against osteoarthritis. ${ }^{21}$ Isonicotinic acid also known as Pyridine-4-carboxylic acid is an organic compound with a carboxyl group on a pyridine ring. It is an isomer of nicotinic acid and the carboxyl group for isonicotinic acid is on the 4-position instead of the 3-position for nicotinic acid. It is non-hazardous and non-carcinogenic. It is stable at high temperature $3000 \mathrm{C}$. The isonicotinic acid derivatives namely Rimifon and Marsilid have been used as a potential drug against pulmonary tuberculosis, and in the treatment of bone and joint tuberculosis. ${ }^{22,23}$ In the present study, Lutein was modified by appending pyridine moiety for increased antioxidant activity and its ability to inhibit $\mathrm{H}_{2} \mathrm{O}_{2}$ induced TGF- $\beta 1$ expression in peripheral blood mononuclear cells was investigated. The peripheral blood mononuclear cells are used with the rationale that they are easy to achieve, relatively robust but heterogeneous cell types and limited replication. It is reported that these cells are found suitable for functional analysis of polymorphisms in the TGF- $\beta$ signalling pathway.

\section{Materials and methods}

\section{Materials}

Lutein was obtained from Sigma-Aldrich (St. Louis, MO). All the other chemicals and solvents used were of analytical grade from Merck Biosciences India Pvt. Ltd. Multispecies TGF- $\beta 1$ ELISA kit (\#KAC1688) was procured from Invitrogen Corporation, CA. RPMI1640 medium, fetal bovine serum (FBS), bovine serum albumin (BSA), trypsin-EDTA, Hank's Balanced Salt Solution (HBSS), sodium bicarbonate, gentamycin, phosphate- buffered saline (PBS), Triton $\mathrm{X}-100$, penicillin and streptomycin was procured from SigmaAldrich (St. Louis, MO).

\section{Human peripheral lymphocyte isolation and culture}

The peripheral lymphocytes were isolated from $15 \mathrm{ml}$ of freshly drawn venous blood from healthy male donors aged between 25-30years. Blood was collected in anticoagulant Acid Citrate Dextrose (ACD: $85 \mathrm{mM}$ citric acid, $71 \mathrm{mM}$ trisodium citrate, $165 \mathrm{mM}$ D-glucose) in the ratio of 5:1. Four volumes of hemolysing buffer $\left(0.85 \% \mathrm{NH}_{4} \mathrm{Cl}\right.$ in $10 \mathrm{mM}$ Tris buffer, $\left.\mathrm{pH} 7.4\right)$ was added, mixed well and incubated at $40 \mathrm{C}$ for $30 \mathrm{~min}$. Then the cells were centrifuged at $1200 \mathrm{rpm}$ for $12 \mathrm{~min}$, the supernatant was discarded, pellet was washed again in $5 \mathrm{ml}$ of hemolysing buffer and the cell pellet was washed thrice with $10 \mathrm{ml}$ of $\mathrm{HBSS}\left(137 \mathrm{mM} \mathrm{NaCl}, 5 \mathrm{mM} \mathrm{KCl}, 0.8 \mathrm{mM} \mathrm{MgSO}_{4}\right.$, $5 \mathrm{mM}$ D-glucose in $8.5 \mathrm{mM}$ phosphate buffer $\mathrm{pH} 7.4$ ) and suspended in the same buffer solution. Cells were suspended in RPMI-1640 media supplemented with $12 \%$ fetal calf serum supplemented with glutamine. Temperature was maintained at $370^{\circ} \mathrm{C}$ in a humidified $5 \%$ $\mathrm{CO}_{2}$ incubator. ${ }^{24}$ The medium was changed at intervals of $24 \mathrm{hrs}$.

\section{Cell viability assay}

The cells are removed from the medium replaced with $100 \mu \mathrm{L}$ of fresh culture medium. $10 \mu \mathrm{L}$ of the $12 \mathrm{mM}$ MTT (3-(4,5-Dimethylthiazol2-yl)-2,5-Diphenyltetrazolium Bromide) stock solution was added to each well. A negative control of $10 \mu \mathrm{L}$ of the MTT stock solution added to $100 \mu \mathrm{L}$ of medium alone was used. The cells were incubated at $37^{\circ} \mathrm{C}$ for $4 \mathrm{hrs} .100 \mu \mathrm{L}$ of the SDS-HCl solution was added to each well and mixed thoroughly. The microplate was incubated at $37^{\circ} \mathrm{C}$ for $4 \mathrm{hrs}$ in a humidified chamber. ${ }^{25}$ Each sample was mixed and the absorbance was read at $570 \mathrm{~nm}$.

\section{Derivatization of lutein by condensation reaction}

Lutein Derivatization by condensation reaction using pyridine4-carboxylic acid was carried out with modifications the method reported earlier. ${ }^{26} 21 \mathrm{mg}$ of pyridine-4-carboxylic acid was treated with $33 \mathrm{mg}$ of DCC in the presence of $25 \mathrm{ml}$ of DMF as a solvent medium for reaction to occur in a round bottom flask. The mixture was stirred for $15 \mathrm{~min}$ to form an intermediate. To this intermediate, $100 \mathrm{mg}$ of Lutein was added, stirred for $24 \mathrm{hrs}$ to obtain Pyridine appended Lutein along with a minor product dicyclohexyl uridine (DHU). The Pyridine appended Lutein was transferred to the separating funnel followed by the addition of chloroform:water (1:1). After vigorous shaking Pyridine appended Lutein present in the chloroform phase was separated and stored in a dark brown bottle at $-200 \mathrm{C}$ for further studies.

\section{Purification pyridine appended lutein using silica gel chromatography and HPLC}

Pyridine appended Lutein was purified using 10\% silica gel 60-120 mesh suspended in n-hexane. The slurry was packed onto $25 X 1.2 \mathrm{~cm}$ column. 1mg of Pyridine appended Lutein in hexane was loaded onto the column and eluted with n-hexane:ethyl acetate in the ratio of $70: 30(\mathrm{v} / \mathrm{v})$. The fractions were collected at a flow rate of $2 \mathrm{ml} / 5 \mathrm{~min}$. The fractions showing maximum absorbance at $454 \mathrm{~nm}$ were pooled and further concentrated by Rotavapor. ${ }^{27}$ The HPLC purification was done using Agilent 1260 Infinity Quaternary LC System composed of G1311B/C Quaternary Pump, G1329B Autosampler, G1330B Thermostat and G4212B DAD. The HPLC system was equipped with Eclipse plus C18 column (4.6X150mm I.D., $5 \mu \mathrm{m}$ particle). The analysis of the chromatographic data was carried out on Open lab CDS ChemStation software (A.01.05). The fractions were eluted at the rate of $1 \mathrm{ml} / \mathrm{min}$ using water, acetonitrile, methanol and dichloromethane as mobile phase in the ratio $0.5: 9.5: 67.5: 22.5$.

\section{Analysis of pyridine appended lutein by liquid chromatography mass spectrometery}

The Pyridine Appended Lutein was analyzed by LCMS. MS was carried out in the positive ion measurement mode with a detection voltage of $1.6 \mathrm{kV}$, with the flow rate of the nebulizer gas was $2.5 \mathrm{ml} /$ min. Full scan spectra were obtained by scanning masses between $\mathrm{m} / \mathrm{z}$ 100 and 700.

\section{Scavenging activity against DPPH radical}

The effect of Pyridine appended Lutein on the DPPH radical was estimated according to the method of reported earlier. ${ }^{28} 100 \mathrm{mM}$ Tris$\mathrm{HCl}$ buffer $(500 \mu 1, \mathrm{pH} 7.4)$ with $150 \mu 1$ of the DPPH in ethanol was mixed to a final concentration of $250 \mu \mathrm{M}$ with or without aliquots of Pyridine appended Lutein, unmodified Lutein and BHA ( 0 to $1.70 \mu$ moles in $30 \mu \mathrm{l} \mathrm{each}$ ). The mixture was shaken vigorously and left to stand at room temperature for $20 \mathrm{~min}$ in the dark. The absorbance at $517 \mathrm{~nm}$ of the reaction solution was measured spectrophometrically. The DPPH decolourization of the sample was calculated according to the following equation as, $\%$ decolourization $=(1-$ Absorbance of sample/Absorbance of control) X 100.

\section{Quantitative determination of TGF- $\beta$ I using ELISA}

TGF- $\beta 1$ was quantified using multispecies TGF- $\beta 1$ kit as per the manufacturer's instruction. The Invitrogen Multispecies TGF$\beta 1$ kit is a solid phase sandwich ELISA. A monoclonal antibody specific for TGF- $\beta 1$ coated onto the wells of the microtiter strips were used. Samples, including standards of known TGF- $\beta 1$ content, 
control specimens, and unknowns $\left(3 \mathrm{mM} \mathrm{H}_{2} \mathrm{O}_{2}\right)$ treated peripheral blood mononuclear cells with or without 0 to $2.70 \mu$ moles of Pyridine appended Lutein and unmodified Lutein each, were pipetted into these wells, and followed by the addition of a biotinylated secondary antibody. After removing excess detection antibody, streptavidinperoxidase was added. After a second incubation and washing to remove the entire unbound enzyme, a substrate solution was added, which was acted upon by the bound enzyme to produce color. The intensity of the colored product measured at $450 \mathrm{~nm}$ was directly proportional to the concentration of TGF- $\beta 1$ present in the sample.

\section{Statistics}

Analysis of Variance (ANOVA) test, followed by individual comparison by Student's ' $t$ '-test, for the determination of level of significance among the mean \pm SEM, in various groups were performed.

\section{Results}

\section{Derivatization of Lutein by condensation reaction}

In the present investigation, Lutein was derivatized by condensation reaction using pyridine-4-carboxylic acid. $21 \mathrm{mg}$ of pyridine-4-carboxylic acid when treated with $33 \mathrm{mg}$ of DCC in the presence of $25 \mathrm{ml}$ of DMF as a solvent medium yielded $2.28 \mathrm{mg} / \mathrm{ml}$ of pyridine appended Lutein along with a minor product dicyclohexyl uridine (DHU). The pyridine appended Lutein showed maximum absorbance at $454 \mathrm{~nm}$

\section{Purification pyridine appended lutein using silica gel chromatography and HPLC}

Purification using silica gel (60-120 mesh) showed two peaks, with major peak at $454 \mathrm{~nm}$ and minor peak at $477 \mathrm{~nm}$. The fractions which showed maximum absorbance at $454 \mathrm{~nm}$ were pooled and concentrated using Rotavapor. The dried pyridine appended Lutein was suspended in methanol and further purified by HPLC and fractions were eluted at the rate of $1 \mathrm{ml} / \mathrm{min}$ using water, acetonitrile, methanol and dichloromethane as mobile phase in the ratio 0.5:9.5:67.5:22.5. A major peak was obtained at $454 \mathrm{~nm}$ with retention time of $1.60 \mathrm{~min}$. Unmodified Lutein showed single major peak at $444 \mathrm{~nm}$ with retention time of $1.82 \mathrm{~min}$ (Figure 1A \& 1B).

\section{Analysis of pyridine appended lutein by liquid chromatography mass spectrometery}

The Pyridine Appended Lutein analyzed by LCMS gave an molecular mass of $650 \mathrm{Da}$ confirming the compound as parent molecule Lutein appended with pyridine moiety (Figure 2).

\section{Scavenging activity against DPPH radical}

Pyridine appended Lutein at $0.42 \mu$ moles showed $91.60 \%$ of DPPH radical scavenging activity in comparison to unmodified Lutein $(80.76 \%)$, whereas, butylated hydroxy anisole (BHA) scavenged DPPH radicals by $88 \%$. Further, increasing the concentrations of unmodified Lutein and BHA from $0.42 \mu$ moles up to $1.70 \mu$ moles showed moderate increase in DPPH scavenging activity to $86.18 \%$ and $89.4 \%$ respectively. There was no significant change in the DPPH scavenging activity by pyridine appended Lutein by increasing the concentration to $1.70 \mu$ moles. The unmodified Lutein and BHA showed maximum scavenging activity of $86.18 \%$ and $89.4 \%$ when used at concentrations 2.97 folds higher than pyridine appended Lutein (Figure 3). According to the statistical analysis the values were considered significant at $\mathrm{p}<0.05$ from $0.42 \mu$ moles.
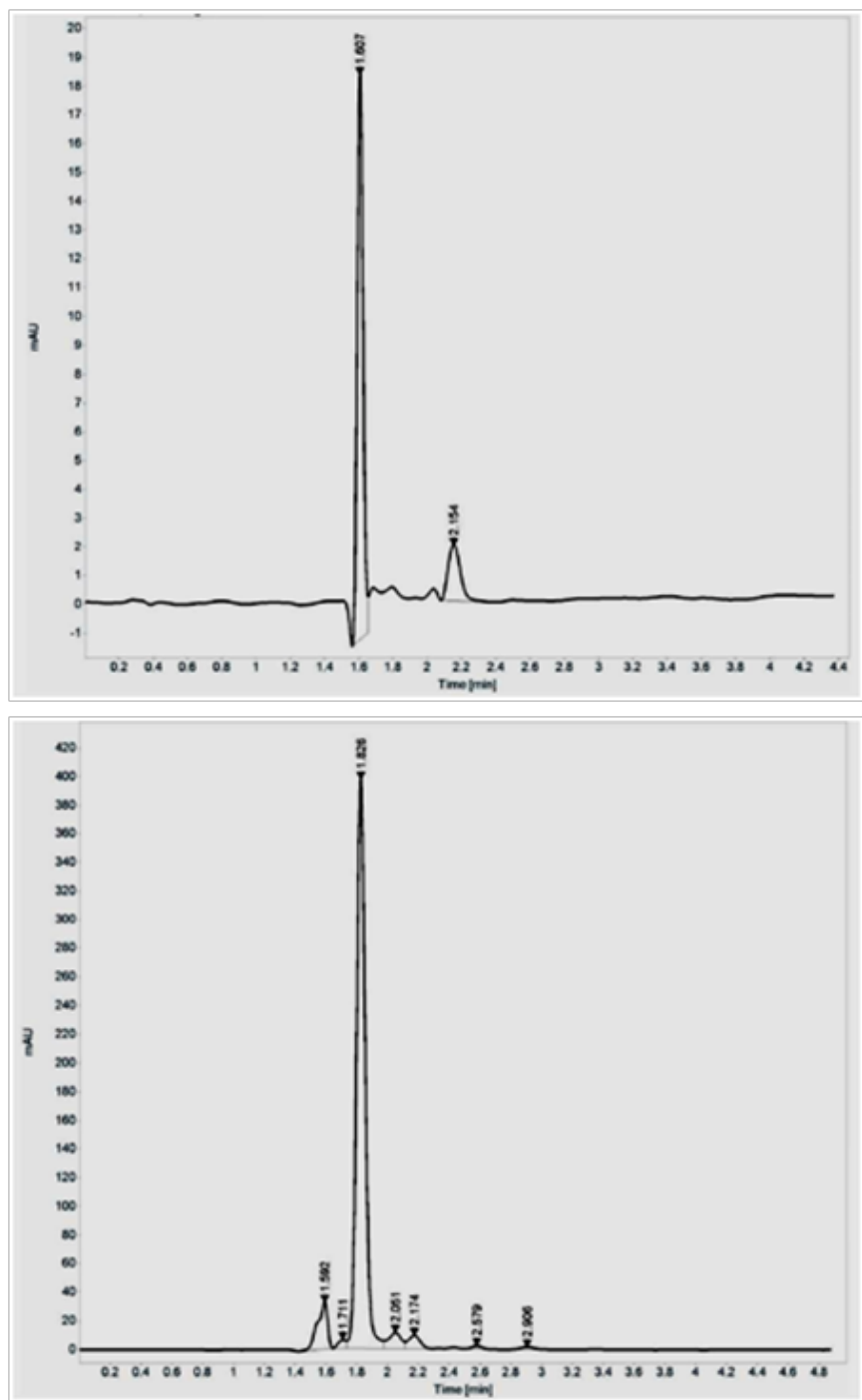

Figure I HPLC purification of pyridine appended Lutein (A) and unmodified Lutein (B) on Agilent 1260 Infinity Quaternary LC System composed of GI3IIB/C Quaternary Pump, GI329B Autosampler, GI330B Thermostat, G42 I 2B DAD equipped with Eclipse plus CI 8 column (4.6XI50mm I.D., $5 \mu \mathrm{m}$ particle). The analysis of the chromatographic data was carried out on Open lab CDS ChemStation software (A.0I.05). The fractions were eluted at the rate of $\mathrm{Iml} / \mathrm{min}$ using water, acetonitrile, methanol and dichloromethane as mobile phase in the ratio $0.5: 9.5: 67.5: 22.5$.

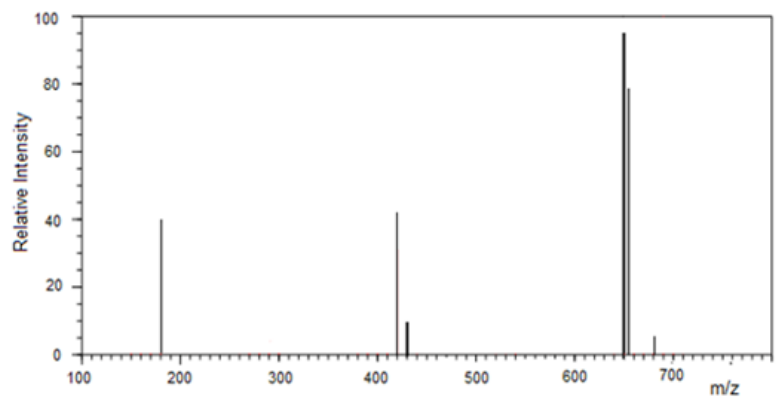

Figure 2 Analysis of Pyridine Appended Lutein by Liquid Chromatography Mass Spectrometery.

The Pyridine Appended Lutein was analyzed by LCMS. MS was carried out in the positive ion measurement mode with a detection voltage of $1.6 \mathrm{kV}$, with the flow rate of the nebulizer gas was $2.5 \mathrm{ml} / \mathrm{min}$. Full scan spectra were obtained by scanning masses between $\mathrm{m} / \mathrm{z} 100$ and 700 . 


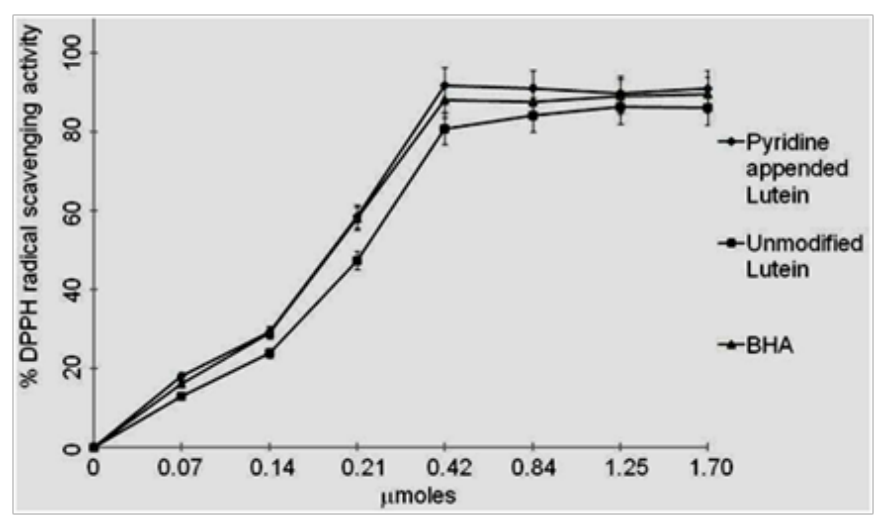

Figure 3 Scavenging activities against DPPH radical. $100 \mathrm{mM}$ Tris-HCl buffer $(500 \mu \mathrm{l}, \mathrm{pH} 7.4)$ and $\mathrm{I} 50 \mu \mathrm{l}$ of the DPPH mixed in ethanol to a final concentration of $250 \mu \mathrm{M}$ with or without pyridine appended Lutein, unmodified Lutein and $\mathrm{BHA}$ as mentioned in methods. The DPPH decolourization of the sample was calculated according to the following equation as, $\%$ decolourization= (I-Absorbance of sample/Absorbance of control) $X 100$. The assay was performed in triplicates and the values are expressed as Mean $\pm \mathrm{SD}$.

\section{Quantitative determination of TGF- $\beta$ I using ELISA}

Effect of pyridine appended Lutein on TGF- $\beta 1$ expression in $\mathrm{H}_{2} \mathrm{O}_{2}$ treated peripheral blood mononuclear cells was examined. After pretreatment with different concentrations of pyridine appended Lutein and unmodified Lutein $(0-2.70 \mu \mathrm{moles})$ for $30 \mathrm{~min}$, the cells were cultured with $\mathrm{H}_{2} \mathrm{O}_{2}(3 \mathrm{mM})$ for $48 \mathrm{hrs}$. Pyridine appended Lutein and unmodified Lutein at $0.92 \mu$ moles inhibited TGF- $\beta 1$ expression in $\mathrm{H}_{2} \mathrm{O}_{2}(3 \mathrm{mM})$ treated peripheral blood mononuclear cells by $83.14 \%$ $(152.1 \mathrm{pg} / \mathrm{ml})$ and $76.21 \%(214.62 \mathrm{pg} / \mathrm{ml})$ respectively compared to $\mathrm{H}_{2} \mathrm{O}_{2}$ treated cells $(902.15 \mathrm{pg} / \mathrm{ml})$ without test samples (Figure 4). Further increase in the concentrations of pyridine appended Lutein from $0.92 \mu$ moles to $2.70 \mu$ moles did not show significant inhibition of TGF- $\beta 1$ expression, whereas unmodified Lutein showed $79.26 \%$ of inhibition. The cell viability was always above $90 \%$ in the assay performed. The pyridine appended Lutein and unmodified Lutein was not cytotoxic even at concentrations at $5.0 \mu$ moles (Table 1). According to the statistical analysis the values were considered significant at $\mathrm{p}<0.05$ from $0.92 \mu$ moles.

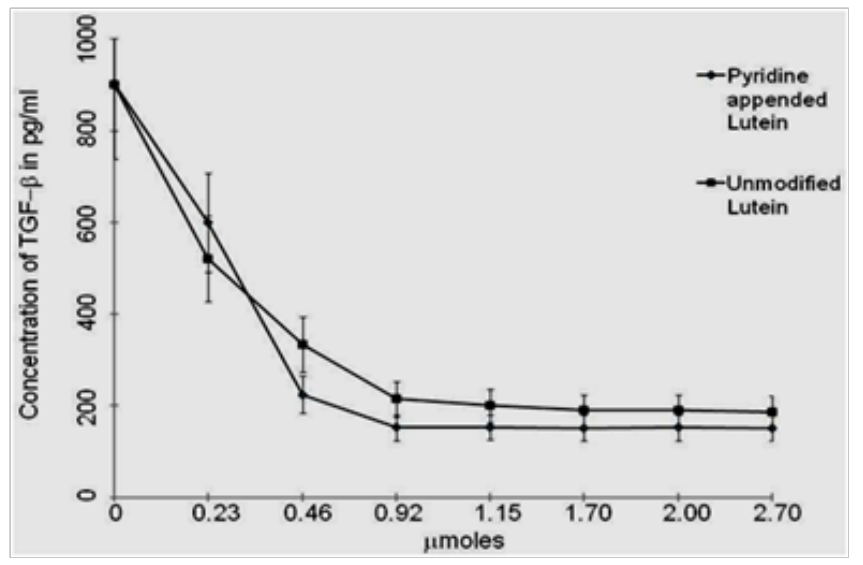

Figure 4 Quantitative determination of TGF- $\beta$ I using ELISA with samples, including standards of known TGF- $\beta$ I content, control specimens, and unknowns $\left(3 \mathrm{mM} \mathrm{H}_{2} \mathrm{O}_{2}\right)$ treated peripheral blood mononuclear cells with or without Pyridine appended Lutein and unmodified Lutein. The intensity of the colored product measured at $450 \mathrm{~nm}$ was directly proportional to the concentration of TGF- $\beta$ I present in the sample. The assay was performed in triplicates and the values are expressed as Mean \pm SD.
Table I The cell viability assay

\begin{tabular}{lll}
\hline \multirow{2}{*}{$\begin{array}{l}\text { Concentration } \\
\text { in } \mu \text { moles }\end{array}$} & \% of Cells viable & \\
\cline { 2 - 3 } & Pyridine appended lutein & Unmodified lutein \\
\hline 0.5 & $96 \pm 5.0$ & $95 \pm 6.0$ \\
2 & $95 \pm 6.0$ & $94 \pm 4.0$ \\
5 & $96 \pm 4.7$ & $96 \pm 5.2$ \\
\hline
\end{tabular}

\section{Discussion}

This study demonstrated the synthesis of pyridine appended Lutein by treating Lutein with Isonicotinic acid (Pyridine-4-carboxylic acid) in the presence of DCC and DMF, further examined the effect of pyridine appended Lutein on DPPH radical scavenging activity and TGF- $\beta$ expression in $\mathrm{H}_{2} \mathrm{O}_{2}$ treated peripheral blood mononuclear cells.

The xanthophyll Lutein is not endogenously synthesized by the human body and tissue levels therefore depend on dietary intake. ${ }^{29}$ Lutein is an antioxidant which is believed to be an essential nutrient for normal vision. ${ }^{30}$ Studies have also indicated that Lutein improves heart health, protects skin against UV damage, reduces oxidative stress, and possesses anti-inflammatory and anti-cancer properties. ${ }^{31}$ Lutein is hydrophobic in nature since the presence of long carbon chain and therefore its uptake is bound to fats. Better absorption could be achieved by enhancing water solubility. This may increase the antioxidant properties as well. Several studies are reported on the introduction of novel reactions to Lutein chemistry. ${ }^{12,13}$ In recent years, attempts have been made to increase the hydrophilicity of Lutein due to its potential applications in the medicine and food industries. Pyridine is a heterocyclic organic compound with the chemical formula $\mathrm{C}_{5} \mathrm{H}_{5} \mathrm{~N}$. It is structurally related to benzene, with one $\mathrm{CH}$ group replaced by a nitrogen atom. It is used as a precursor to agrochemicals and pharmaceuticals and is also an important solvent and reagent. Pyridine is found to be a very versatile nucleus in the pharmaceutical field. The derivatives are very much used as anticancer, antimicrobial, antiviral, antidiabetic \& antithrombic agents etc. ${ }^{32}$ In the present investigation, the pyridine appended Lutein showed a maximum absorbance at $454 \mathrm{~nm}$ compared to unmodified Lutein $(444 \mathrm{~nm})$. According to Fieser Rule, the absorption maxima of the plant pigments increases with the number of newly added conjugated double bonds, alkyl substituents, endocyclic and exocyclic double bonds. ${ }^{33}$ Hence the increase in the maximum absorption for pyridine appended Lutein might be due to the additional pyridine group conjugated to the Lutein.

Lutein is shown to possess pronounced free radical scavenging ability due to its polarity and number of conjugated double bonds, ${ }^{11}$ was appended with pyridine moiety. Pyridine derivatives are also shown to possess significant DPPH radical scavenging activity. ${ }^{34,35}$ Thus chemical synthesis of such derivatives has shown to possess better biological activity. The presence of the pyridine moiety increased the DPPH radical scavenging activity probably due to enhanced proton donor capacity. On the other hand, Pyridine ring is known to increase the lipophilic character of the molecule Lutein, which facilitates the crossing through the biological membranes, thus increasing the availability of the Lutein for improved antioxidant activity. Alkyl groups at positions 2 and 4 of a pyridine ring are more reactive and carbanions can be formed readily at alkyl carbons attached at the 2and 4-positions. This increased chemical reactivity is used to form the pyridine appended derivative. Chemical reactivity of pyridines is a function of ring aromaticity, presence of a basic ring nitrogen atom, 
$\pi$-deficient character of the ring, large permanent dipole moment, easy polarizability of the $\pi$-electrons, activation of functional groups attached to the ring, and presence of electron-deficient carbon atom centres at the $\alpha$ - and $\gamma$-positions. Depending on the conditions of the chemical transformation, one or more of these factors can give rise to the observed chemistry. The Ring-atomic centres can undergo attack by electrophiles, easily at the ring nitrogen and less easily at ring carbons. Nucleophile attack is also possible at ring carbons or hydrogens. The strong biological activity of pyridine appended Lutein could be due to the fact that the molecule makes the electrons more delocalized. ${ }^{36}$ ROS are excessively produced in several disease states, and their injurious effects may contribute to the pathogenesis of many diseases. The relationship between increased ROS synthesis and the cellular functional and morphological changes has been explored using various experimental approaches. ROS vary in their inherent reactivates, stability, chemistry, and diffusibility. $\mathrm{H}_{2} \mathrm{O}_{2}$, in most biological contexts, is generally less reactive and more long-lived than either superoxide anion or hydroxy radical. Moreover, $\mathrm{H}_{2} \mathrm{O}_{2}$ is lipid-soluble and can diffuse across biological membranes. Most studies of $\mathrm{H}_{2} \mathrm{O}_{2}$ have focused on its role in mediating intracellular signal transduction by its ability to oxidize cysteine residues in the catalytic domains of protein tyrosine phosphatases. ${ }^{37,38}$ Biological effects of extracellular $\mathrm{H}_{2} \mathrm{O}_{2}$ have been primarily studied by adding exogenous $\mathrm{H}_{2} \mathrm{O}_{2}$ to target cells. ${ }^{39}$

TGF- $\beta$ is a potent fibrogenic cytokine and found to induce oxidative stress. Oxygen derivatives, acting as secondary intracellular messengers, have been shown to activate transcription factors, such as nuclear factor $-\kappa \mathrm{B}(\mathrm{NF}-\kappa \mathrm{B})$ and activated protein -1 (AP-1). ROS may stimulate the transcription and production of TGF- $\beta$. The role of $\mathrm{TGF}-\beta$ in inducing extracellular matrix production is widely reported. TGF- $\beta$ levels are known to be significantly elevated in $\mathrm{H}_{2} \mathrm{O}_{2}$ treated wounds thus indicating the involvement of $\mathrm{H}_{2} \mathrm{O}_{2}$ in activating TGF $-\beta$. There are several approaches reported to neutralize TGF- $\beta$ activity. These include use of proteoglycan decorin, soluble TGF- $\beta$ type II receptors and gene therapy approaches ${ }^{40}$ From the study it is understood that pyridine appended Lutein could serve as much better approach for neutralizing $\mathrm{TGF}-\beta 1$ activity at much lesser concentrations than unmodified Lutein or Pyridine alone.

\section{Conclusion}

In conclusion, the present study showed that the newly synthesized pyridine appended Lutein showed remarkable increase in DPPH radical scavenging activity at very low concentration than unmodified Lutein and further significantly inhibited $\mathrm{H}_{2} \mathrm{O}_{2}$ induced TGF- $\beta 1$ expression in peripheral blood mononuclear cells.

\section{Acknowledgements}

The study was funded by Science and Engineering Research Board (SERB) of Dept. of Science and Technology (DST), Govt. of India under Fast Track Scheme (No. SR/FT/LS-159/2010).

\section{Conflict of interest}

The author declares no conflict of interest.

\section{References}

1. Wilhelm S, Helmut S. Bioactivity and protective effects of natural carotenoids. Biochim Biophys Acta. 2005;1740(2):101-107.

2. Milan D, Josef T, Radek L, et al. Role of carotenoids in Light-Harvesting processes in an antenna protein from the chromophyte Xanthonema debile. J Phys Chem. 2012;116:8880-8889.
3. Davood N, Masoud H, Salar H, et al. Analysis of carotenoid production by Halorubrum sp. TBZ126; an extremely halophilic archeon from urmia lake. Adv Pharm Bull. 2014;4(1):61-67.

4. Crews H, Alink G, Andersen R, et al A critical assessment of some biomarker approaches linked with dietary intake. $\mathrm{Br} J$ Nutr. 2001;86(suppl 1):S5-S35.

5. Stahl W, Sies H. Lycopene: a biologically important carotenoid for humans? Arch Biochem Biophys. 1996;336(1):1-9.

6. Landrum JT, Bone RA. Lutein, zeaxanthin, and the macular pigment. Arch Biochem Biophys. 2001;385(1):28-40.

7. Johnson EJ. The role of carotenoids in human health. Nutr Clin Care. 2002;5(2):56-65.

8. Keyvan K, Raluca R, Wenhua L, et al. The Role of Lutein in Eye-Related Disease. Nutrients. 2013;5(5):1823-1839.

9. Joanna F, Kvetoslava B. Potential Role of Carotenoids as Antioxidants in Human Health and Disease. Nutrients. 2014;6(2):466-488.

10. Alves RA, Shao A. The science behind lutein. Toxicol Lett. 2004;150(1):57-83.

11. Edakkadath RS, Korengath CP, Ramadasan K. Antioxidant activity of carotenoid lutein in vitro and in vivo. Ind J Exp Biol. 2010;48(8):843848 .

12. Magdolna H, Veronika N, Jozsef D, et al. Hydrophilic Carotenoids: Recent Progress. Molecules. 2012;17(5):5003-5012.

13. Tsuboi M, Etoh H, Yomoda Y, et al. Nitration reaction of lutein with peroxynitrite. Tetrahedron Lett. 2010;51(4):676-678.

14. Takashi M, Harukuni T, Nobutaka S, et al. Anti-Oxidative, Anti-TumorPromoting, and Anti-Carcinogensis activities of Nitroastaxanthin and Nitrolutein, the reaction products of Astaxanthin and Lutein with Peroxynitrite. Mar Drugs. 2012;10(6):1391-1399.

15. Khachik F, Chang AN, Gana A, et al. Partial synthesis of (3R,6'R)alpha-cryptoxanthin and (3R)-beta-cryptoxanthin from (3R, $\left.3^{\prime} \mathrm{R}, 6^{\prime} \mathrm{R}\right)$ lutein. J Nat Prod. 2007;70(2):220-226.

16. Thannickal VJ, Fanburg BL. Reactive oxygen species in cell signaling. Am J Physiol Lung Cell Mol Physiol. 2000;279(6):L1005-L1028.

17. Jones DP, Go YM, Anderson CL, et al. Cysteine/cystine couple is a newly recognized node in the circuitry for biologic redox signaling and control. FASEB J. 2004;18(11):1246-1248.

18. Hong YH, Peng HB, La Fata V, et al. Hydrogen peroxide mediated transcriptional induction of macrophage colony-stimulating factor by TGF- $\beta 1$. J Immunol. 1997;159:2418-2423.

19. Jiang Z, Seo JY, Ha H, et al. Reactive oxygen species mediate TGF$\beta 1$ induced plasminogen activator inhibitor-1 upregulation in mesangial cells. Biochem Biophys Res Commun. 2003;309(4):961-966.

20. Gharaee-Kermani M, Hu B, Phan SH, et al. Recent advances in molecular targets and treatment of idiopathic pulmonary fibrosis:focus on TGF-beta signaling and the myofibroblast. Curr Med Chem. 2009;16(11):1400-1417.

21. Maria CS, Lourenco M, de Souza VN, et al. Evaluation of anti-tubercular activity of nicotinic and isoniazid analogues. ARKIVOC. 2007;15:181191.

22. Steenken W, Wolinsky E. Anti tuberculous properties of hydrazines of isonicotinic acid (rimifon, marsilid). Am Rev Tuberc. 1952;65(4):365375 .

23. Bosworth DM, Fielding JW, Wilson H, et al. A comparison of the efficacy of iproniazid (marsilid) and isoniazid (rimifon) in the treatment of bone and joint tuberculosis. Sea View Hosp Bull. 1955;15(3):125-133. 
24. Rao RP, Gowda SST, Leela S. Smoke treatment triggers the release of a novel DNA damaging factor by lymphocytes. Mol Cell Biochem. 2006;284(1-2):73-79.

25. Chung WB, Backstrom, McDonald J, et al. The (3-(4,5dimethylthiazol-2-yl)-2,5-diphenyltetrazolium) colorimetric assay for the quantitation of Actinobacillus pleuropneumoniae cytotoxin. Can $J$ Vet Res. 1993;57(3):159-165.

26. Thomas E. Stabilized esters of Lutein. 2008.

27. Panatpong B, Thanawich O, Phattanon P, et al. Purification of free lutein from marigold flowers by liquid chromatography. Eng J. 2012;16:145155 .

28. Yamaguchi T, Takamura H, Matoba T, et al. HPLC method for evaluation of the free radical-scavenging activity of foods by using 1,1-diphenyl-2picrylhydrazyl. Biosci Biotechnol Biochem. 1998;62(6):1201-1204.

29. Elton RK, Jogchum P, Guido R, et al. The Effect of Modified Eggs and an Egg-Yolk Based Beverage on Serum Lutein and Zeaxanthin Concentrations and Macular Pigment Optical Density: Results from a Randomized Trial. PLOS ONE. 2014;9(3):1-9.

30. Hossein B, Michele M, Gislin D. Lutein supplementation in retinitis pigmentosa: $\mathrm{PC}$-based vision assessment in a randomized doublemasked placebo-controlled clinical trial [NCT00029289]. BMC Opthalmol. 2006;6:23-34.

31. Choudhary R, Tandon RV. Consumption of functional food and our health concerns. Pak J Physiol. 2009;5(1):76-83.

32. Ajit C, Pandeya SN. Pyridine, a versatile nucleus in pharmaceutical field. Asian J Pharma Clin Res. 2011;4:5-8.
33. Woodward RB. Structure and Absoprtion Spectra. IV. Further Observations on $\alpha, \beta$-Unsaturated Ketones. $J$ Am Chem Soc. 1942;64(1):76-77.

34. Shadab A, Rakesh P, Monica K. Antitubercular, antioxidant and in vitro anti-inflammatory activity of some newly synthesized chalcones. Ind $J$ Chem. 2014;53B:440-443.

35. Fadda AA, Berghot MA, Amer FA, et al. Synthesis and Antioxidant and Antitumor Activity of Novel Pyridine, Chromene, Thiophene and Thiazole Derivatives. Archiv der Pharmazie. 2012;345(2):378-385.

36. Mohammed AH. A Convenient Mechanism for the Free Radical Scavenging Activity of Resveratrol. Int J Phytomed. 2011;3(4):459-469.

37. Lee S R, Kwon K S, Kim SR, et al. Reversible inactivation of proteintyrosine Phosphatase 1B in A431 cells stimulated with epidermal growth factor. J Biol Chem. 1998;273(25):15366-15372.

38. Jones DP, Go YM, Anderson CL, et al. Cysteine/cystine couple is a newly recognized node in the circuitry for biologic redox signaling and control. FASEB J. 2004;18(11):1246-1248.

39. Kamsler A, Segal M. Hydrogen peroxide as a diffusible signal molecule in synaptic plasticity. Mol Neurobiol. 2004;29(2):167-178.

40. Sanchez A, Alvarez AM, Benito M, et al. Apoptosis induced by transforming growth factor-beta in fetal hepatocyte primary cultures: involvement of reactive oxygen intermediates. $J$ Biol Chem. 1996;271(13):7416-7422. 